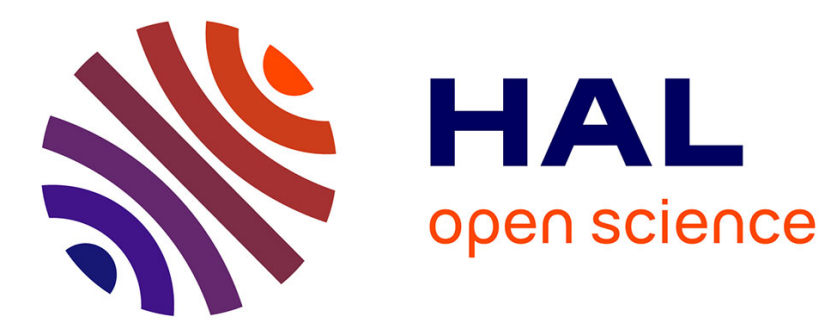

\title{
'Credibility as a trade off' in electricity industries, a first evaluation
}

Yannick Perez

\section{To cite this version:}

Yannick Perez. 'Credibility as a trade off' in electricity industries, a first evaluation. Global Business and Economics Review, 2005, 7, pp.278 - 278. 10.1504/GBER.2005.007621 . hal-01424509

\section{HAL Id: hal-01424509 \\ https://hal.science/hal-01424509}

Submitted on 2 Jan 2017

HAL is a multi-disciplinary open access archive for the deposit and dissemination of scientific research documents, whether they are published or not. The documents may come from teaching and research institutions in France or abroad, or from public or private research centers.
L'archive ouverte pluridisciplinaire HAL, est destinée au dépôt et à la diffusion de documents scientifiques de niveau recherche, publiés ou non, émanant des établissements d'enseignement et de recherche français ou étrangers, des laboratoires publics ou privés. 


\title{
'Credibility as a trade off' in electricity industries, a first evaluation
}

\author{
Yannick Perez \\ ADIS- GRJM, Université de Paris-Sud 11, \\ 91405 Orsay cedex, Paris, France \\ E-mail: yannick.perez@jm.u-psud.fr
}

\begin{abstract}
In the early 1990s, Pablo Spiller worked on North \& Williamson's application of the New Institutional Economics, on the conditions of credible network reforms. Credibility is defined as the capacity to provide reform commitments. This work, started from a Positive Political Economics Veto Point Model, has been constructed and applied with good results. The Author will show the consequences of the 'credibility as a trade off' concept in the efficiency of Regulatory Instruments studied and then introduce two improvements. Self-Regulation is introduced and their performance reconsidered in order to achieve the trade off between commitment and flexibility.
\end{abstract}

Keywords: credibility; electricity; reform; new institutional economics.

Reference to this paper should be made as follows: Perez, Y. (2005) "Credibility as a trade off' in electricity industries, a first evaluation', Global Business and Economics Review, Vol. 7, Nos. 2/3, pp.278-291.

Biographical notes: Yannick Perez is Tenured Associate Professor of Economics at University of Paris-Sud XI since 2003. He is member of the Groupe Réseaux Jean-Monnet at the ADIS lab (www.grjm.net). He is interested in Electricity Market Reforms, Industrial Organisation and Institutional Economics. Yannick Perez gained a $\mathrm{PhD}$ in Economics at the University Paris 1 Panthéon-Sorbonne and a Master in Economics both in University of Paris I Panthéon-Sorbonne \& Ecole Normale Supérieure de Fontenay St-Cloud. He is also teaching Theories of Organisations and Markets and European Institutions \& Competition Policies for master students in the University Paris-Sud XI.

\section{Introduction}

In the early 1990s Spiller and others ${ }^{1}$ have worked on an application and extension of the new institutional economics framework of North (1991) and Williamson $(1985,1996,2002)$ under conditions of credible market reforms. In this framework proposed by Spiller, the credibility of network industries reforms is defined as the capacity to provide a competitive stability of commitments, and it depends on the design of the Regulatory Instruments and the nature of the institutional environment which is given in the short run. The Spiller's work, started from an initial Positive Political Economy Veto Point Model (Tsebelis, 2002), has been constructed and applied with good results in many countries and network industries. But this success story shows today its limits in two dimensions: First, some successful reforms are not very well described or 
understood in this framework. Newbery (1999), Glachant and Finon (2003) argue that electricity reform credibility in England and Wales is not rooted in huge checks and balances, but in the regulatory agency discretionary powers. Shirley (2002) and Noll (2002) also argue that even in very weak and poor institutional design, the introduction of well crafted contracts in network industries can solve some major institutional flaws; Glachant et al. (2003) highlight the fact that in some institutional environments, a regulatory agency is not always needed if competitor authorities and self regulation work efficiently to secure access to the 'essential facilities'. Second, a growing literature starts to underline the need to reconsider the initial set of assumptions used by some authors like Rufin (2003), who identifies a 'Presidential Bias' in the Spiller et al. framework. In order to deal with these critics, I propose to improve the set of assumptions (Spiller's and other analytical) by introducing a 'trade off logic' in the initial definition of credibility that has been used.

I think that these logical difficulties can by solved by an analytical return to Spiller's initial model, supporting all the empirical appreciations and the recommendations of economic policies which are related with it. The intuition of our paper is rooted in the basic Transaction Cost Economic's ex ante ex post contractual problem: in fact, Spiller's model is logically flawed by the impossibility of guaranteeing a perfect regulatory contract, ex ante. This classical contractual problem introduces the necessity of an ex post set of solutions, and also of room for flexibility in case of unanticipated events. This need for flexibility to correct imperfections of the initial agreement raises the question of the trade off logic between commitment and flexibility. In our perspective, this trade off has to be managed by the Regulatory Instruments and will permit us to propose a new definition of credibility in network industries.

The paper is organised as follows: Section 2 presents Spiller's initial model (1998); Section 3 proposes an extension and a reinterpretation of Spiller's classical Regulatory Instruments classification. The last section concludes the discussion and proposes new directions to be drawn up, based on this reinterpretation.

\section{The model of Spiller: an analysis in terms of 'veto players'}

\subsection{Description of the model}

In the study of Guasch and Spiller (1999) and of Spiller (1998), the main Regulatory Instruments are studied in the light of their capacity to resist the transformations due to the principal actors' preferences. For these authors, the design of the governance structures must mainly allow the stability of commitment of stakeholders according to the institutional environments. According to them, there are four principal Regulatory Instruments, which can be isolated, to control the transformation of the regulation of networks industries.

- The first Regulatory Instrument is the introduction of a 'specific legislation' which includes, by a legislative process, the new operating modes of the studied sector, the distribution of the capacities between the regulator and the operators.

- The second Regulatory Instrument is in the introduction of 'Presidential decrees'. The decree can transform the old type of regulation by a new one, only under the will of the President ${ }^{2}$ of the studied ${ }^{3}$ nation. 
- The third Regulatory Instrument is the 'licence agreement' which was very strongly developed in the Nineties following the development of the English reforms. ${ }^{4}$

- The last Regulatory Instrument relates more particularly to the United States of America; these are specialised in a specific mode of regulation by 'administrative procedures'. They are characterised by formal procedures of decision making which the agencies must respect, and the appeal of these decisions by independent legal authorities (Mc Cubbins et al., 1987, 1989).

To illustrate the credibility differences of the Regulatory Instruments, Spiller (1998) introduces a veto player model. To show the influence of the institutional environments on the stability of competitive commitment, the authors distinguish three of them:

- The First is the US system of 'Presidential checks and balances' characterised by a strict separation of the executive, legislative (assumption of bicameral system) and judicial powers. In this institutional environment, each player has a veto right which can block the reform process.

- A deterioration of the first model of strict separation of the powers is characterised by forms of 'false bicameral system' which induces a great proximity of the veto points of the two rooms.

- The last institutional environment characterises the situation of the 'parliamentary' political systems equipped with a significant concentration of the legislative and executive powers. The parliamentary systems are characterised by the control of the legislative and executive powers by a single political party, which results in very close veto points.

To determine if a Regulatory Instrument is more constant than another according to the institutional environments, they propose to test the stability of the reform vis $\grave{a}$ vis a modification of the preferences of the three powers. If a modification of the preferences of the actors cannot modify the agreement initially concluded, then the Regulatory Instrument will be credible in the interpretation of Spiller.

\subsection{The credibility of regulation by a specific legislation}

I take again the presentation of the assumptions with the same notation.

Case 1: Specific legislation and modification of the preferences in a decentralised institutional environment without courts.

In this institutional environment the veto players are:

- $\mathrm{H}$, who represents the preferential point of the Lower House, (House).

- $\mathrm{S}$, who represents the preferential point of the Upper House (Senate).

- $\quad \mathrm{P}$, who represents the preferential point of the executive power (President).

- $\mathrm{W}$, who represents the whole possibility of equilibrium choices included in the triangle of the possible solutions $\mathrm{W}(\mathrm{H}, \mathrm{S}, \mathrm{P})$. Inside this triangle, it is possible to define an item $X \phi$ which represents a reform which would have the agreement of the three actors $\mathrm{H}, \mathrm{S}, \mathrm{P}$. To have equilibrium, $X \phi$ must be included in the initial triangle of the solutions W (H, S, P). 
By an external simulated shock, the preferential points of the three actors move towards a new triangle W1 $(\mathrm{H} 1, \mathrm{~S} 1, \mathrm{P} 1)$. The initial equilibrium $X \phi$ is not included in the initial triangle of the possible agreements between the three stakeholders of the reform. As $X \phi$ is not any more an equilibrium, the law will be amended, and the new equilibrium point becomes $X 1$.

This first case leads to two conclusions: a specific legislation can be a stable mode of governance in a decentralised institutional environment with 'checks and balances' only if the modification of the initial preferences is not too significant; or if the surface of the triangle of the possible common choice is very large and $\mathrm{W} 1(\mathrm{H} 1, \mathrm{~S} 1, \mathrm{P} 1)$ is included in the initial triangle $\mathrm{W}(\mathrm{H}, \mathrm{S}, \mathrm{P})$. These two conditions are very restrictive, and it is difficult to consider that this governance mode using specific legislation is a sufficient guarantee of the stability of the reform.

Figure 1 Case 1: Specific legislation and modification of the preferences in an institutional environment decentralised without course of justice

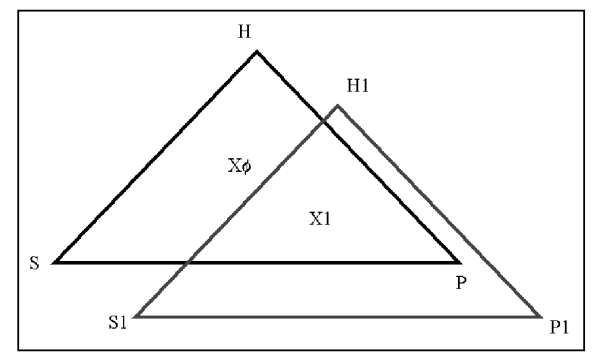

Source: Guash and Spiller (1999) Chapter 6

Case 2: Specific legislation and modification of the preferences in a distorted decentralised institutional environment, without courts.

In this second case, the introduction of a distorted 'bicameral' structure makes it possible to show the concentration effect of the capacities on the triangle surface, of possible agreements $\mathrm{W}$. The more the bicameral system is distorted by institutional rules which bring closer the preferential points of the two houses, the more the shocks and modifications of the preferential points have a significant impact on the form of the agreement (see Figure 2).

Figure 2 Case 2: Specific legislation and modification of the preferences in a weak decentralised institutional environment, without course of justice

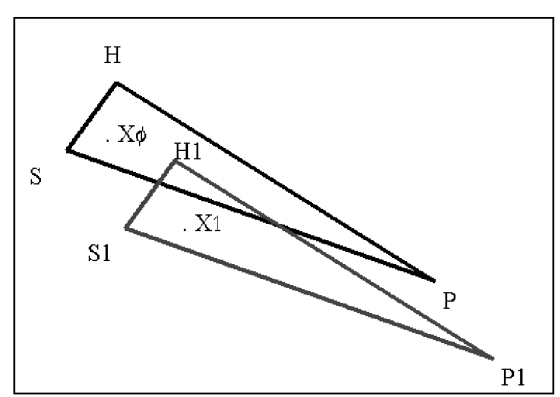

Source: Guash and Spiller (1999) Chapter 6 
The introduction of this analysis of the bicameral structures shows a problem of commitment stability. This problem increases by the concentration of the capacities and the reduction of the size of the triangle. So it is difficult to argue that the stability of the introduced reform will be resistant to a modification of veto points, and the concentration power poses a problem of stability of commitments. The two identified stability conditions in the first model are considerably reduced: a specific legislation can be a stable mode of governance in a decentralised institutional environment of bicameral system distorted only if the modification is minor. It is also possible to consider that W1 $(\mathrm{H} 1, \mathrm{~S} 1, \mathrm{P} 1)$ is included in the initial triangle $\mathrm{W}(\mathrm{H}, \mathrm{S}, \mathrm{P})$, but in this case, the exogenous shock is of a very weak magnitude.

Case 3: Specific legislation and modification of the preferences in a parliamentary system.

Spiller (1998) shows then the reduction operated on the surface of the triangle of agreement by the introduction of a parliamentary structure. Moreover, (3) P, which represents the preferential point of the executive power (President) leaves the place to the point ( $\left.3^{\prime}\right)$ E, which represents the preferential point of the executive power (Government) (see Figure 3).

Figure 3 Case 3: Specific legislation and modification of the preferences in a parliamentary system

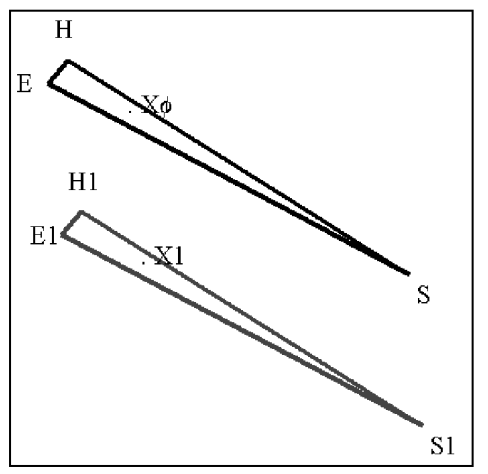

Source: Guash and Spiller (1999) Chapter 6

Figure 4 Case 4: the license agreement in a parliamentary system

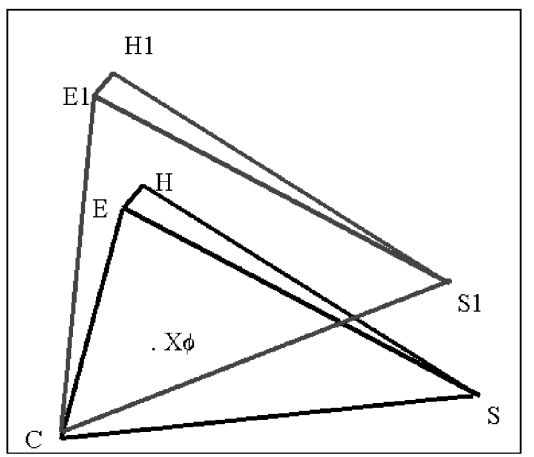

Source: Guash and Spiller (1999) Chapter 6 
Let us introduce an external shock and a new triangle W1 (H1, S1, E1). This shock makes it possible to test the stability of this governance structure. The initial equilibrium $X \phi$ cannot belong any more to the triangle of the possible solutions. The problem lies in the narrowness of the field of possible agreements.

To conclude, the specific legislation never seems a dominating type of stable mode of governance, because this mode is always likely to be modified by an exogenous shock which moves the initial preference points. Concretely, this point is significant because the mode of regulation by a specific legislation is unable to provide stable guarantees.

Case 4: The licence agreement in a parliamentary system.

It is very difficult for governments to be engaged in a stable way in a regulatory governance structure with Specific Legislation which guarantees the stability of the process vis à vis the shocks: another Regulatory Instrument introduced through the licence agreements. The major characteristics of licences are that they include at the same time, the rights and the obligations of the contractors, as well as the safeguards supported by the civil courts. The main interest is that the courts guarantee what ensures the stability of the contracts without the intervention of administrative procedures. ${ }^{5}$ These safeguards protect them from modifications of the initial contract. Indeed, in the case of any modification of the licence agreements having to meet the agreement of the controlled company, this additional veto point offers to the controlled company, guarantees of stability. If I introduce this additional point into the case No. 3, I will obtain the following situation: (1), (2) and ( $\left.3^{\prime}\right)$, remain identical; and addition of the veto player $\mathrm{C}$, which represents the preferential point of the controlled company (5). So the initial triangle of preferences changes and takes the form $\mathrm{W}\left(4^{\prime}\right)^{\prime}$ which represents the area of possible agreements included in $\mathrm{W}(\mathrm{H}, \mathrm{S}, \mathrm{E}, \mathrm{C})$. In this case, to be a situation of equilibrium, $X \phi$ must thus be included in $\mathrm{W}(\mathrm{H}, \mathrm{S}, \mathrm{E}, \mathrm{C})$.

If the preferential points of the three actors move towards a new triangle W1 (H1, S1, $\mathrm{E} 1, \mathrm{C})$, it appears as the situation of initial equilibrium, where $X \phi$ is still part of the area of the possible agreements between the four players. As $X \phi$ remains equilibrium between the reform producers, the regulation will not be modified. The Spiller model (1998) reveals the essential characteristics of the licence agreements in this institutional environment. It creates a fix point $\mathrm{C}$, which partially stabilises the structure of preferences.

\subsection{The stability of the regulation by administrative procedures}

The USA represents an academic case of the use of administrative procedures. These procedures simultaneously determine the way in which the agencies make their decisions and the legal procedures of appealing their decisions. In this institutional environment characterised by an intense division of power, at the same time functional and territorial, the capacity of action and intervention of the governance structure is set on the administrative procedures. There are also detailed possible grounds for appeal on the decisions of the agencies of regulation (McCubbins et al., 1987, 1989; Moe and Howell, 1999; Moe and Cadwell, 1994; Lijphart, 1999; Haggard 2000; Haggard and McCubbins, 2001; Glachant and Finon, 2000; Brousseau and Glachant, 2002).

The advantages of this system are obviously its stability and the very significant protection of the operators who can only be expropriated with difficulty by the public 
authorities. McCubbins et al. (1987) specify that each agency is very precisely equipped with written rules which mainly result in a slow down of the process of regulation. As a consequence, this form of governance can produce stability only if the judicial power is technically able to oppose the decisions of the executive power. ${ }^{6}$ To demonstrate this last point, it is necessary to introduce judicial power into the former models.

\subsection{The introduction of the courts into the model as a guarantee of the stability of commitments}

The courts can have a significant impact on the production process of the reform by the possibilities of appeal which offer legal supervision of the legislative and executive activities. In the study of stability of reforms, it is also significant to characterise the incidence of the introduction of the courts into the former reasoning. To simplify, I will consider only the two extreme cases of institutional environments, the presidential system of 'checks and balances' and the parliamentary system.

Case 5: Courts and decentralised institutional environment.

This devolution is studied in the case of the presidential regime with bicameral structure characterised by a strict separation of powers and distant veto points. This institutional environment offers consensual laws that can be modified with much difficulty. Thanks to the model of Spiller (1998), the introduction of the courts allows some form of selection of options: the initial points (1), (2), (3) and the initial triangle of the preferences (4) to which one adds the courts. Therefore, let us postulate that there are two types of courts. The Court of Justice close to the solution of initial equilibrium $X \phi$ which will be noted as $\mathrm{SCH}$ (6). Therefore, $\mathrm{SCH}$ represents the circle of the equilibrium points of the courts (Supreme Court) receptive to the point of view of the Upper and Lower Houses. The second Court favours equilibrium inside $\mathrm{W}(\mathrm{H}, \mathrm{S}, \mathrm{P})$ which will be noted as $X a$. This second Court will be noted as SCL (7). SCL represents the circle of preferences of the court (Supreme Court) near to the executive powers and Upper House. As $X a$ and $X \phi$ are included in $\mathrm{W}(\mathrm{H}, \mathrm{S}, \mathrm{P})$, they both constitute solutions which satisfy the constraints posed by the three actors $\mathrm{H}, \mathrm{S}, \mathrm{P}$ which have veto rights. But the point $X a$ is different from initial $X \phi$. If this second point better satisfies the operators submitted to the governance structure, they can take recourse to the second Court of Justice to influence the selection of the point $X a$ which is more favourable to them (see Figure 5).

Figure 5 Case 5: courses of justice and decentralised institutional environment

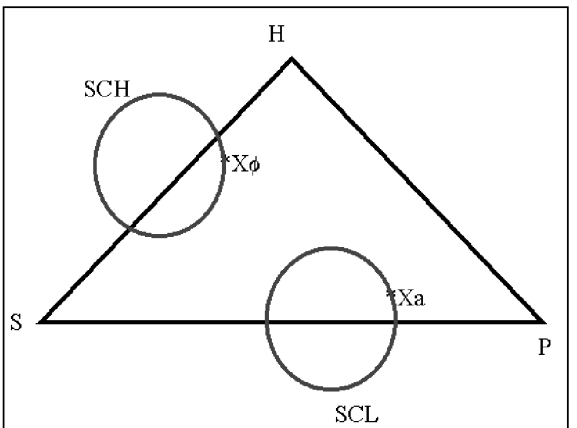

Source: Guash and Spiller (1999) Chapter 6 
Spiller (1998) showed that the role of the judicial power was to select from among different equilibriums ( $X a$ and $X \phi)$ which are in competition, the final adopted solution. By doing this, the established final regulation will be modified by the capacities of appeal to the courts. So, the more the capacities of appeal are numerous, the more the influence of the judicial power on the solution selections will be significant.

It can now be seen that the impact of the courts in parliamentary systems characterised by a strong concentration of the executive and legislative powers is much less decisive in guaranteeing the stability of commitment. Indeed, the parliamentary systems are facing few difficulties for being flexible, but on the other hand, they suffer from a lack of stability of commitments.

Case 6: Courts and parliamentary systems.

These are the points, (1), (2), (3') and the initial triangle of the preference (4). Also let us note $\left(6^{\prime}\right) \mathrm{SC}$ (Supreme Court) which represents the circle of the preferential points of the courts. Within the initial triangle of preferences (4), it is possible to define an $X \phi$ which represents a mode of governance which has the consensus of the four actors $\mathrm{H}, \mathrm{S}, \mathrm{E}, \mathrm{SC}$ (to see Figure 6).

Figure 6 Case 6: courts and the parliamentary system

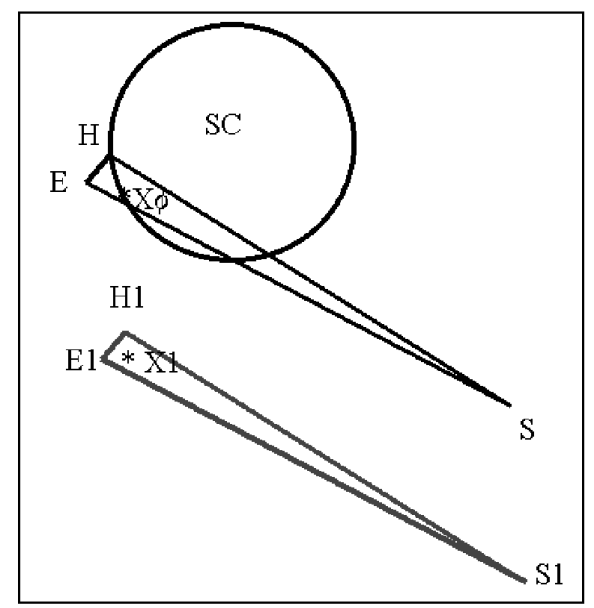

Source: Guash and Spiller (1999) Chapter 6

If one postulates that the preferential points of the three actors $\mathrm{H}, \mathrm{S}, \mathrm{E}$ moves towards a new triangle $\mathrm{W} 1$ (H1, S1, E1), the equilibrium becomes $X 1$, and this one is outside of circle SC. The court faces a dilemma: Either it lets things go and does not intervene to support the initial solution $X \phi$, or it opposes to this decision and tries to support $X \phi$ against the three other actors. This situation of opposition is not sustainable with regard to the concentration of the powers which exist in parliamentary systems.

\subsection{Summary of the Spiller model}

For simplification, I have represented in the following table, the main results permitted by the veto point model, that Spiller used as a basic tool in his various analyses of regulations across countries and industries. 
This previous point permits us to make obvious, the limits found in our earlier works trying to apply the Spiller analytical framework to European Electricity Reforms (Perez, 2002; Perez, 2003a, 2003b; Glachant et al., 2003).

\subsection{Limits of the Spiller model}

I propose to underline two limits and an extension:

The first limit is related to the focus on the sole dimension of stability of commitments. However in these reforms of networks industries, in the absence of a perfect and complete model of substitution being easily duplicated, there is a need for adjustment mechanisms for correcting errors. These errors are caused by a lack of information or rationality. Examples of the need for these corrections in networks industries cannot be discussed any more as it has been shown by the many adjustments introduced in Englandand Wales, in Germany, in Spain and in California, in the electricity sector, for example. The last study of Holburn and Spiller (2002) on this sector has one logical implication. It is necessary to reconsider the question of the realisation of an arbitrage between the needed stability of commitments and the need for leaving margins of flexibility to correct the imperfections in the economic rules and structures. However these authors will not develop this towards the final conclusion of their logical requirement and do not produce the revaluation of the initial model.

The analytical bias in favour of the US model: Perez (2002) and Rufin (2003) also underline that there is a bias in the Spiller framework in favour of the American institutional environment which is used as the reference model. I think that the tools developed by Spiller are very useful and very effective as I will show in the following section, regarding the condition of making an effort and being willing to reconsider interpretations of the initial results. If flexibility becomes a virtue in a trade off logic, the only stability stops being a sufficient guarantee of the effectiveness and the credibility of reforms. Thus the basic regulatory instruments will have to offer the capacity to produce a trade off between commitment and flexibility.

In this paper I want to take into account a 5th basic instrument which is self regulation by the actors themselves. This specific tool is not introduced in the Spiller literature, but some European extensions of his previous works by Perez (2002), Glachant et al. (2003) and Dubois (2004) allows us to introduce it in the next section.

\section{Spiller's model, complemented and reinterpreted}

\subsection{A fifth element: self regulation}

In their paper, Glachant et al. (2003) introduce into the basic regulatory instruments of regulation, the role of private associations and their capacity for self organisation. They describe that self regulation can effectively work in the German institutional environment. Indeed, the German Competition Authority plays the role of 'a competition activist' using two complementary mechanisms of

- periodic negotiation of the association's agreements

- by the threat of an institutional blocking which would lead to a rigid and constraining national law. 
I will present, using Spiller's formalisation, this new Regulatory Instrument. The three actors who have a veto right are two principal associations VIK, VDEW, and the Competition Authority BKA. In the first phase, the Association Agreements called $V V I{ }^{7}$ starting May 1998 and the agreement called $V V I I,{ }^{8}$ December 1999, were negotiated on an entirely private basis by the $\operatorname{VIK}^{9}$ (association of large industrial electricity consumers) on the one side, and the VDEW, ${ }^{10}$ the association of German electricity companies, on the other. The main difference with the model of Spiller (1998) is the endogenous character of the shocks which are produced endogenously by the Competition Authority without modifying the whole regulatory system. This Competition Authority is an objective 'associate' with the big consumer association VIK, and, these two veto players produce shocks in order to make WDEW's position change inside the triangle of solutions W (VDEW, VIK, BKA).

This repeated and scheduled shock produces new negotiations between the associations and also new agreements named VVI, VVII and VVII+ which all are inside the first triangle $\mathrm{W}$.

As Glachant et al. (2003) note, this competitive dynamic works because of: 1-a 'competitive ratchet effect' introduced by the Competition Authority; 2-a progressive and planned sequence of negotiations and 3-a not infinite dynamics and the absence of VV3 negotiations planned for the moment. The more impressive result of this German reform is the evolution of the VDEW's position, who agreed on major competition improvements requested by VIK and BKA in a decentralised and federal institutional environment (see Figure 7).

Figure 7 The Self regulation solution between associations and competition authority in Germany

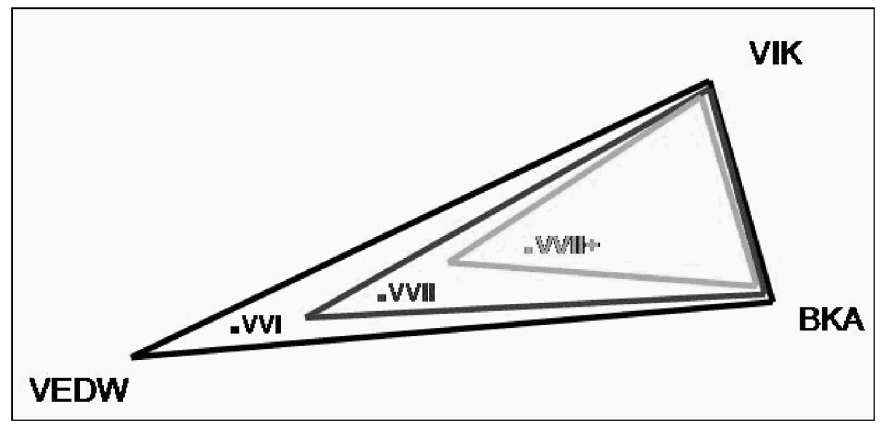

\subsection{Toward a reevaluation of the performances of the regulatory instruments}

It is significant here to stress that the various basic mechanisms of regulation do not have the same capacities to produce, at the same time, stability of engagements and flexibility and that the initial evaluation of Spiller (1998) summarised in Table 1 will be transformed by our logic in terms of trade off. I will just make some preliminary remarks. 
Table 1 The summary of the results obtained with the Spiller model

\begin{tabular}{lllll}
\hline & $\begin{array}{l}\text { Specific } \\
\text { legislation }\end{array}$ & $\begin{array}{l}\text { Presidential } \\
\text { decrees }\end{array}$ & $\begin{array}{l}\text { Licence } \\
\text { agreements }\end{array}$ & $\begin{array}{l}\text { Administrative } \\
\text { Procedures }\end{array}$ \\
\hline Presidential & $\begin{array}{l}\text { Very weak } \\
\text { guarantee }\end{array}$ & No guarantee & Good guarantee & Good guarantee \\
$\begin{array}{l}\text { Weak } \\
\text { bicameralism }\end{array}$ & $\begin{array}{l}\text { Very weak } \\
\text { guarantee }\end{array}$ & No guarantee & Good guarantee & Weak guarantee \\
Parliamentary & No guarantee & No guarantee & Only guarantee & No guarantee \\
\hline
\end{tabular}

I highlight that only two combinations of one regulatory instrument and one institutional regime are 'balanced', i.e., achieve both commitment and flexibility. The first one is characterised by the instrument of Self regulation and environment of Institutional checks and balances. The second one is parliamentary institutional environment with licence agreements. All the other solutions are not able to achieve a good mix between the two goals addressed to them.

The following point concerns the administrative procedures. This tool is very strong in Spiller's analytical framework because it is a strong guarantee of the stability of commitment reinforced by courts. In our view, this presidential bias as Perez (2002) and Rufin (2003) argue is not sound in analytical terms. This tool is only efficient in the specific 'institutional environment' of 'checks and balance' and only in the focus on stability.

\subsection{The consequence of the 'credibility as a trade off'}

In Levy and Spiller's (1994) words, three types of restrictions contribute to the credibility of a regulation:

- substantive restraints on the discretion of the regulator

- formal or informal constraints on changing the regulatory system

- institutions that enforce the above-substantive or procedural-constraints.

These three types of restrictions clearly postulate that the first designed reform is effective and that the main problem consists in maintaining in place this brand new structure of regulation. Our intuition here is rather basic: instead of considering that the credibility of the reforms in network industries is solely based on the stability of commitments, I now judge credibility by a logical comparison between commitments and flexibility. This flexibility is needed as an analytical tool to allocate a capacity to correct the errors made in the initial design rules and in the governance structures. This intuition produces a major change in analytical terms. The evolution that I propose is to consider that a Regulatory Instrument should not only guarantee the stability of commitments, but also guarantee that all needed evolutions of the rules of the game are not the expression of the opportunistic behaviour of one of the stakeholders in the reform who succeeded in lobbying. Thus the logical standard to seek to determine the reforms credibility is for each Regulatory Instrument to use its capacity to guarantee the stability of commitments while permitting the necessary evolution of the rules of the game, as long as it is not the expression of the opportunistic behaviour of stakeholders. 


\section{Conclusions and agenda of the research}

The research agenda defined by this reinterpretation is manifold: on the one hand it is possible to correct the 'strange' choices within the Spiller (1998) initial model. As I see it, these two strange choices are the main focus of the stability of commitments and the emphases on administrative procedures with courts intervention; on the other hand, the logical study of each combination of the Regulatory Instrument must be reinterpreted and opens the way to many complementary theoretical and empirical studies;

Finally, in terms of recommendations for economic policies, it seems that the description of the credibility of the reforms as a trade off between ex ante stability and ex post flexibility make it possible to clarify the needs of both contractors and public reformers for a long term regulatory contract. This contract needs to be corrected on a regular basis to be in line with the evolution of knowledge, information and specific or general economic evolutions. As I have shown here, special attention has to be paid to the credibility definition of the network reforms as the "capacity to guarantee the stability of commitments while allowing the necessary evolution of the rules of the game, if this flexibility will not be the expression of stakeholders" opportunistic behaviour.

\section{Acknowledgement}

I would like to thank Professors Gentzoglanis and Pinto Jr for their remarks in the BESI conference panel on electricity reforms.

\section{References}

Brousseau, E. and Glachant, J.M. (Eds.) (2002) The Economics of Contracts: Theories and Applications Chapter 1 Introduction, Cambridge University Press, pp.3-31.

Dubois, U. (2004) 'Pablo Spiller et les principes du design institutionnel des réformes', Working Paper GRJM, Université Paris-Sud 11, www.grjm.net

Glachant, J-M. and Finon, D. (2000) 'Why do the European union's electricity industries continue to differ?', in Menard, C. (Ed.): Institutions, Contracts and Organizations, Edward Elgar, London, pp.432-456.

Glachant, J-M. and Finon, D. (Eds.) (2003) 'Competition in European electricity markets', A Cross-Country Comparison, Edward Elgar, p.392.

Glachant, J.M., Dubois, U. and Perez, Y. (2003) 'Deregulating with no regulator: is Germany electricity transmission regime institutionally correct?', ISNIE Conference at the Budapest University of Economics, September 11-13, www.isnie.org.

Guash, J.L. and Spiller, P.T. (1999) Managing the Regulatory Process: Design, concepts, Issues, and the Latin America and Caribbean Story Chapter 6, The International Bank for Reconstruction and Development, the World Bank, Washington DC.

Haggard, S. (2000) 'Interest, institutions and policy reform', in Krueger, A.O. (Ed.): Economic Policy Reform: The Second Stage, Chicago University Press, pp.21-61.

Haggard, S. and McCubbins, M.D. (Eds.) (2001) President, Parliaments and Policy, Collection Political Economy of Institutions and Decisions, Cambridge University Press, pp.1-20.

Holburn, G.L.F. and Spiller, P.T. (2002) 'Institutional or structural: lessons from international electricity sector reforms', in Brousseau, D.E. and Glachant, J.M. (Eds.): The Economics of Contracts: Theories and Applications, Cambridge University Press, pp.463-502. 
Levy, B. and Spiller, P.T. (1994) 'The institutional foundations of regulatory commitment: a comparative analysis of telecommunications regulation', Journal of Law, Economics, and Organization, Vol. 10, No. 2.

Levy, B. and Spiller, P.T. (Eds.) (1996) Regulations, Institutions and Commitment. Comparative Studies of Telecommunications, Cambridge University Press.

Lijphart, A. (1999) Patterns of Democracy, Governments Forms and Performance in 36 Countries, Yale University Press.

McCubbins, M.D., Noll, R.G. and Weingast, B.R. (1987) 'Administrative procedures as instruments of political control', The Journal of Law, Economics and Organisation, Vol. 3, pp.243-277.

McCubbins, M.D., Noll, R.G. and Weingast, B.R. (1989) 'Structures and process, politics and policy: administrative procedures and the political control of agencies', Virginia Law Review, Vol. 75, pp.431-482.

Moe, T.M. and Caldwell, M. (1994) 'The institutional foundation of democratic government : a comparison of presidential and parliamentary systems', Journal of Institutional and Theoretical Economics150/1.

Moe, T.M. and Howell, W.G. (1999) 'The presidential power of unilateral action', The Journal of Law, Economics and Organization, Vol. 15, No. 1.

Newbery, D.M. (1999) Privatisation Restructuring, and Regulation of Network Utilities, The MIT Press, Cambridge, Massachusetts, London, England.

Noll, R.G. (2002) 'The economics of urban water systems chap 2', in Shirley, M.M. (Ed.): Thirsting for Efficiency, The Economics and Politics of Urban Water System Reform, The World Bank and Pergamon, pp.43-64.

North, D.C. (1991) Institutions, Institutional Change and Economic Performance, Cambridge University Press.

Perez, Y. (2002) L'analyse Néo-institutionnelle des réformes Électriques Européennes, Thèse de doctorat Université de Paris I Panthéon Sorbonne.

Perez, Y. (2003a) The Feasibility of European Electricity Reforms, a New-Institutional Economics Evaluation, in Polityka Energetyczna, tom 6, pp.55-64.

Perez, Y. (2003b) L'attractivité des Réformes Pour le Gouvernement, un Problème de Mesures? article présenté au colloque Histoire et Gestion des Organisations, Novembre, Université de Toulouse.

Rufin, C. (2003) The Political Economy of Institutional Change in the Electricity Supply Industry, Edward Elgar, p.240.

Savedorff, W.D. and Spiller, P.T. (1999) Spilled Water: Institutional Commitment in the Provision of Water Services, Inter-American Development Bank editor.

Shirley, M.M. (Ed.) (2002) Thirsting for Efficiency, The Economics and Politics of Urban Water System Reform, The World Bank and Pergamon.

Shirley, M.M. and Ménard, C. (2002) 'Cities awash: a synthesis of the country cases', in Shirley, M.M. (Ed.): Thirsting for Efficiency, The Economics and Politics of Urban Water System Reform, World Bank and Permagon, pp.1-42.

Spiller, P.T. (1996) 'Institutions and commitments', Industrial and Corporate Change, Vol. 1, pp.421-452.

Spiller, P.T. (1998) 'A positive political theory of regulatory instruments: contracts, administrative law or regulatory specificity?', Southern California Review, Vol. 40, pp.18-35.

Spiller, P.T. and Martorell, L.V. (1996) 'How should it be done? electricity regulation in Argentina, Brazil, Uruguay, and Chile', in Gilbert, R.J. and Kahn, E.P. (Eds.): International Comparisons of Electricity Regulation, Cambridge University Press, pp.82-125.

Spiller, P.T. and Vogelsang, I. (1997) 'The institutional foundations of regulatory commitment in the UK: the case of telecommunications', Journal of Institutional and theoretical Economics, Vol. 153, No. 4, pp.607-629. 
Tsebelis, G. (2002) Veto Players. How Political Institutions Work, Princeton University Press.

Weingast, B.R. (1995) 'The economic role of political institutions: market-preserving federalism and economic development', Journal of Law, Economics and Organisation, April, pp.269-296.

Williamson, O.E. (1985) The Economic Institutions of Capitalism, Free Press.

Williamson, O.E. (1996) The Mechanisms of Governance, Oxford University Press.

Williamson, O.E. (2002) 'The lens of contract: applications to economic development and reform', Conference USAID et IRIS, February 25.

World Bank (1995) Bureaucrats in Business: The Economics and Politics of Government Ownership, Oxford University Press.

\section{Notes}

${ }^{1}$ Levy and Spiller (1994 and 1996) on telecommunications reform, Guasch and Spiller (1999) on reforms in various network industries in Latin America; Spiller and Savedoff (1999) on reforms in water distribution sectors; Spiller and Martorell (1996), Spiller (1998), Holburn and Spiller (2002) on electricity reform. And last, have a look on Spiller et al. (1998) for a econometric test of links between political institutions and electricity investments.

${ }^{2}$ For a systematic study as of these presidential forms of regulation, it is useful to refer to Haggard and Mc Cubbins (2001).

${ }^{3}$ These decrees are used in the Latin America countries of and in Asia.

${ }^{4}$ The English reforms are organised all under this mode of regulation.

${ }^{5}$ Thus in the licence agreements of the regulated British companies, the Price-Caps are registered in the licence agreements and not in the law, or the administrative procedures of control of the regulator, Newbery (1999).

${ }^{6}$ The administrative procedures are very specific to the American institutional environment, and they cannot constitute a stability condition of engagements in the parliamentary systems.

${ }^{7}$ Verbändevereinbarung über Kriterien zur Bestimmung von Durchleitungsentgelten vom 28. Mai 1998.

${ }^{8}$ Verbändevereinbarung über Kriterien zur Bestimmung von Netznutzungsentgelten vom 13. Dezember 1999.

${ }^{9}$ Verband der Industriellen Kraftwirtschaft.

${ }^{10}$ Verband der Deutschen Elektrizitätswirtschaft. 